\title{
Studies on the effect of post harvest treatments on shelf life and quality of mango [Mangifera indica l.]cv. Amrapali
}

\author{
T. Mounika ${ }^{1}$, N. N. Reddy ${ }^{2}$ N. Jyothi lakshmi ${ }^{2 *}$ and Veena Joshi ${ }^{1}$ \\ ${ }^{1}$ College of Horticulture, Sri Konda Laxman Telangana State Horticultural University, Rajendrangar,Hyderabad- \\ 500030 (Telangana), INDIA \\ ${ }^{2}$ Central Research Institute for Dryland Agriculture, Hyderabad-500059 (Telangana), INDIA \\ *Corresponding author. E-mail: lakshmi.jyothi70@gmail.com
}

Received: December 2, 2016; Revised received: May 4, 2017; Accepted: September 20, 2017

\begin{abstract}
The physicochemical characteristics and shelf life of mango[Mangifera indica L.] fruits treated with calcium chloride $\left(\mathrm{CaCl}_{2}-1 \%, 2 \%\right)$, calcium nitrate $\left(\mathrm{Ca}\left(\mathrm{NO}_{3}\right)_{2}-1 \%, 2 \%\right)$,potassium nitrate $\left(\mathrm{KNO}_{3}-1 \%, 2 \%\right)$ and carboxyl methyl cellulose $(\mathrm{CMC}-0.5,1 \%)$ were studied. Untreated fruits served as the control. All tested treatments indicated a significant delay in the change of weight loss $(16.84 \%)$, ripening $(51.66 \%)$,decaying percentage(46.66) and retained firmness $\left(3.23 \mathrm{~kg} / \mathrm{cm}^{2}\right)$ of fruits and biochemical qualities viz., total soluble solids(22.33Brix), sugar accumulation $(18.17 \%)$ and tritratable acidity on $16^{\text {th }}$ day in mango fruits compared to control. The significant $(5 \%)$ impact of treatment is found on the least decay percentage in the order of fruits treated with calcium nitrate (2\%) followed by $1 \%$ $\mathrm{Ca}\left(\mathrm{NO}_{3}\right)_{2}, 2 \% \mathrm{CaCl}_{2}$ and $1 \% \mathrm{CaCl}_{2}$. Hence, it could be concluded that post harvest chemical treatment with calcium nitrate, calcium chloride $(1 \%, 2 \%)$ has the potential to control spoilage, prolong the storage life and preserve valuable attributes of post harvest quality of mango, presumably because of its effect on inhibition of ripening and senescence processes by lowering the respiration rate.
\end{abstract}

Keywords: Amrapali, Calcium chloride, Calcium nitrate,Mango, Shelf life

\section{INTRODUCTION}

Mango (Mangifera indica L.) is one of the most important commercial fruit crops, being referred to as the 'King of fruits'. India accounts for $41 \%$ of world's mango production. Mango is cultivated in an area of 2.2 million hectares with a production of 18.7 million tonnes and a productivity of $8.5 \mathrm{MT} / \mathrm{ha}$. As per (NHB 2016) data base mango occupies $34.9 \%$ of total fruit area, $20.7 \%$ of total fruit production.

Mango has rich diversity with many cultivated varieties and hybrids among them, Amrapali is a well known as a regular bearing dwarf hybrid. The fruit is oblong in shape. The flesh is deep orange red and has about 2.5 to 3.0 times more $\beta$ carotene content indicating higher vitamin A content (Singh and Singh, 2010). Besides, being attractive flesh color, this variety is more suitable for export and processing industry for preparing colored mango nectar and juice. Due to dwarf nature the cultivar is recommended and for high density planting \& kitchen gardens (Ray, 1999).

In the harvesting season, there is a glut of fruits in the market and the post-harvest losses nearly $17-37 \%$ of production (Pulamte Lalsiemlien, 2008). Poor shelf lifeis a major drawback to mango industry (Narendhra,2012). In these days Farmers can't get reasonable price so; it becomes imperative to prolong the shelf life of the fruits in the best interest of farmer's community and consumers as well. Different chemicals and materials have been reported to enhance shelf life of many fruits by maintaining the optimumfirmnessminimize rate of respiration, proteolysis and tissue breakdown. Calcium serves as a binding agent in the form of calcium pectates in the cell walls. Calcium compounds received considerable attention in the recent past due to it delays ripening and senescence, increase firmness, reduces respiration, incidence of physiological disorders, storage rots and extends storage life (Chung et al., 1993). Potassium has been found useful for several fruit crops like citrus, guava and mango as carbohydrate metabolism and its storage are regulated by potassium(Bose et al., 1999).The recent finding that calcium salts interferes with ethylene link to its binding site represents a new and powerful tool for postharvest management of climacteric fruits.It has been demonstrated that the inhibition of the ethylene action delays ripening and senescence. Keeping in view the importance on crop, a study was carried out to study the effect of these compounds on storage life of mango cv. Amrapali.

\section{MATERIALS AND METHODS}

The study was conducted at Horticulture lab, Central Research Institute for Dryland Agriculture (CRIDA), Hyderabad, during the year 2015-16. The fruits of man- 
go cv. Amrapali were harvested from orchard of CRIDAat physiological mature stage. The bruised and diseased fruits were sorted out, and only healthy and uniform sized fruits were selected for the study. The fruits were dip treated with aqueous solution of different chemicals at different concentrations separately each for five minutes. The control fruits were dipped in tap water for five minutes and kept for comparison. The experiment consisted of 9 treatments viz; $\mathrm{T}_{1}-1 \%$ $\mathrm{CaCl}_{2}, \mathrm{~T}_{2}-2 \% \mathrm{CaCl}_{2}, \mathrm{~T}_{3}-1 \% \mathrm{Ca}\left(\mathrm{NO}_{3}\right)_{2}, \mathrm{~T}_{4}-2 \% \mathrm{Ca}$ $\left(\mathrm{NO}_{3}\right)_{2}, \mathrm{~T}_{5}-1 \% \mathrm{KNO}_{3}, \mathrm{~T}_{6}-2 \% \mathrm{KNO}_{3}, \mathrm{~T}_{7}-0.5 \%$ Carboxyl methyl cellulose(CMC), $\mathrm{T}_{8}-1 \% \mathrm{CMC}$ and $\mathrm{T}_{9-}$ Control.Thereafter, the treated fruits as well as control fruits were stored at $21 \pm 2^{\circ} \mathrm{C}$ and $80-85 \%$ Relative Humidity $(\mathrm{RH})$. Each treatment had 3 replications with 10 fruits per replication. The fruits were subjected to physico-chemical analysis at 4 days' interval viz., $0^{\text {th }}$, $4^{\text {th }}, 6^{\text {th }}, 8^{\text {th }}, 12^{\text {th }}$ and $16^{\text {th }}$ day of storage and analyzed statistically following the complete randomized design as out lined by Panse and Sukhatme (1967).

The physiological loss in weight (PLW) after each interval of storage was calculated by subtracting final weight from the initial weight of the fruits and expressed in per cent. The fruit firmness was measured with the help of a penetrometer (Model FT- 327, USA) using $8 \mathrm{~mm}$ stain less steel probe. Ripening was measured by the number of fruits having change in colour from greeninsh to yellow. The ripening percentage was calculated as the number of ripe fruit/total number of fruit $x 100$ and expressed as a percentage. The spoilage percentage was calculated as the number of spoiled fruit/total number of fruit $\mathrm{x} 100$ and expressed as a percentage.

Total soluble solids (TSS) was determined by Hand refractometer and expressed in ${ }^{\circ}$ brix, acidity of fruits by AOAC method (Anon, 1984), total sugars, reducing and non reducing sugar and acidity of fruits were recorded by a method as suggested by Ranganna(1979).

\section{RESULTS AND DISCUSSION}

Physiological loss in weight (PLW\%): The physiological loss in weight (PLW) of fruits, in general, increased with the advancement of storage period rather slowly in the beginning but at a faster pace as the storage period advanced (Fig 1). The fruits treated with $2 \% \mathrm{Ca}\left(\mathrm{NO}_{3}\right)_{2}$ recorded the lowest PLW (16.84\%) on $16^{\text {th }}$ day whereas in control it was $19.83 \%$ recorded on the $8^{\text {th }}$ day of storage. The PLW of fruits treated with $2 \% \mathrm{Ca}\left(\mathrm{NO}_{3}\right)_{2}$ ranged between $3.46-20.44 \%$ from 4 to 20 days of storage as compared to control where it

Table 1. Effect of postharvest treatments on colour change of Mango cv. Amrapali.

\begin{tabular}{|c|c|c|c|c|c|c|}
\hline Treatments & 0 day & $4^{\text {th }}$ day & $8^{\text {th }}$ day & $12^{\text {th }}$ day & $16^{\text {th }}$ day & $20^{\text {th }}$ day \\
\hline $\mathrm{T}_{1}-1 \% \mathrm{CaCl}_{2}$ & Green & $\begin{array}{l}\text { Up to } 25 \% \\
\text { yellow }\end{array}$ & $\begin{array}{l}25-<50 \% \\
\text { yellow }\end{array}$ & $\begin{array}{l}75-100 \% \\
\text { yellow }\end{array}$ & $*$ & $*$ \\
\hline $\mathrm{T}_{2}-2 \% \mathrm{CaCl}_{2}$ & Green & Breaker & $\begin{array}{l}\text { Up to } 25 \% \\
\text { yellow }\end{array}$ & $\begin{array}{l}25-<50 \% \\
\text { yellow }\end{array}$ & $\begin{array}{l}75-100 \% \\
\text { yellow }\end{array}$ & $*$ \\
\hline $\mathrm{T}_{3}-1 \% \mathrm{Ca}\left(\mathrm{NO}_{3}\right)_{2}$ & Green & Breaker & $\begin{array}{l}\text { Up to } 25 \% \\
\text { yellow }\end{array}$ & $\begin{array}{l}25-<50 \% \\
\text { yellow }\end{array}$ & $\begin{array}{l}75-100 \% \\
\text { yellow }\end{array}$ & $*$ \\
\hline $\mathrm{T}_{4}-2 \% \mathrm{Ca}\left(\mathrm{NO}_{3}\right)_{2}$ & Green & Green & Breaker & $\begin{array}{l}\text { Upto } \\
\text { yellow }\end{array}$ & $\begin{array}{l}25-<50 \% \\
\text { yellow }\end{array}$ & $\begin{array}{l}75-100 \% \\
\text { yellow }\end{array}$ \\
\hline $\mathrm{T}_{5}-1 \% \mathrm{KNO}_{3}$ & Green & $\begin{array}{l}\text { Up to } 25 \% \\
\text { yellow }\end{array}$ & $\begin{array}{l}25-<50 \% \\
\text { yellow }\end{array}$ & $\begin{array}{l}75-100 \% \\
\text { yellow }\end{array}$ & * & * \\
\hline $\mathrm{T}_{6}-2 \% \mathrm{KNO}_{3}$ & Green & $\begin{array}{l}\text { Up to } 25 \% \\
\text { yellow, }\end{array}$ & $\begin{array}{l}25-<50 \% \\
\text { yellow, }\end{array}$ & $\begin{array}{l}75-100 \% \\
\text { yellow }\end{array}$ & $*$ & $*$ \\
\hline $\mathrm{T}_{7^{-}}-0.5 \% \mathrm{CMC}$ & Green & $\begin{array}{l}\text { Up to } 25 \% \\
\text { yellow, }\end{array}$ & $\begin{array}{l}25-<50 \% \\
\text { yellow, }\end{array}$ & $\begin{array}{l}75-100 \% \\
\text { yellow }\end{array}$ & $*$ & $*$ \\
\hline $\mathrm{T}_{8^{-}}-1 \% \mathrm{CMC}$ & Green & Breaker & $\begin{array}{l}25-<50 \% \\
\text { yellow, }\end{array}$ & $\begin{array}{l}75-100 \% \\
\text { yellow }\end{array}$ & $*$ & * \\
\hline $\mathrm{T}_{9}$-Control & Green & $\begin{array}{l}25-<50 \% \\
\text { yellow, }\end{array}$ & $\begin{array}{l}75-100 \% \text { yel- } \\
\text { low. }\end{array}$ & $*$ & $*$ & $*$ \\
\hline
\end{tabular}



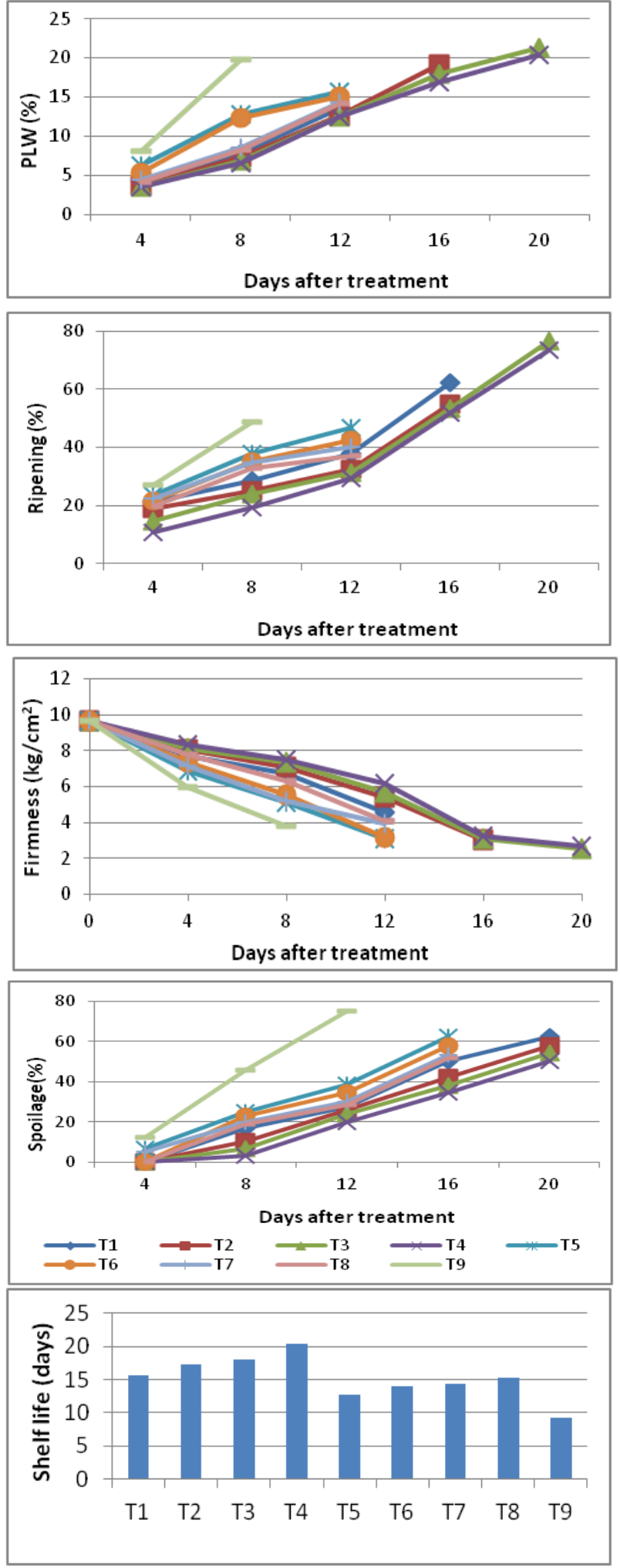

Fig. 1. Effect of post harvest treatments on PLW, Firmness, Ripening, Spoilage, Shelf life of Mango cv. Amrapali $\left(T_{1^{-}}-1 \%\right.$ $\mathrm{CaCl}_{2}, \mathrm{~T}_{2}-2 \% \mathrm{CaCl}_{2}, \mathrm{~T}_{3}-1 \% \mathrm{Ca}\left(\mathrm{NO}_{3}\right)_{2}, \mathrm{~T}_{4}-2 \% \mathrm{Ca}\left(\mathrm{NO}_{3}\right)_{2}, \mathrm{~T}_{5^{-}}$ $1 \% \mathrm{KNO}_{3}, \mathrm{~T}_{6}-2 \% \mathrm{KNO}_{3}, \mathrm{~T}_{7^{-}} 0.5 \% \mathrm{CMC}, \mathrm{T}_{8^{-}} 1 \% \mathrm{CMC}, \mathrm{T}_{9^{-}}$ Control. (CMC)- Carboxyl Methyl Cellulose). ranged between $8.06-19.83 \%$ within the 4-8 days of storage. In the present investigation it was observed that PLW of mango fruits increased with the storage periods irrespective of the treatments. The PLW indicates the progress of ripening in climacteric fruits, higher the PLW more the ripening (Ingle et al., 1981). Post harvest treatments of calcium in the form of calcium nitrate at 2, $1 \%$ concentration significantly reduced the PLW compared to other treatments. Similar results were reported by Mahajan et al. (2008) inplum fruits treated with $2 \% \mathrm{Ca}\left(\mathrm{NO}_{3}\right)_{2}$ were the most firm throughout 7-28 days of storage and showed the lowest physiological weight loss (0.60-2.88\%) after 7-28 days.

Color development: The colour of mango fruits treated with $2 \%$ calcium nitrate obtained $100 \%$ yellow on $16^{\text {th }}$ day but control fruits obtained $100 \%$ yellow on $8^{\text {th }}$ day(Table 1). The fruits softened earlier compared to other treatments due to early formation of carotenoid pigments and loss of tissue turgidity (Leopold, 1964). Colour is one of the most important criteria of quality of most fruits. The changes in colour of mango peel from green to breaker are the most obvious changes which occur during storage of fruits. Change of peel colour during ripening and senescence of fruits involves chlorophyll degradation or qualitative and quantitative alternation of the green pigment into other pigments. During colour change the pulp becomes softer and sweeter as the ratio of the sugar to starch increased and the characteristic aroma is produced.

Firmness $\left(\mathbf{k g} / \mathbf{c m}^{2}\right)$ : It is evident from the data that the fruit firmness, in general followed a declining trend commensurate with advancement in storage period (Fig 1). The fruits treated with $2 \%$ calcium nitrate maintained the highest fruit firmness $6.19 \mathrm{~kg} /$ $\mathrm{cm}^{2}, 3.23 \mathrm{~kg} / \mathrm{cm}^{2}$ on $12^{\text {th }}, 16^{\text {th }}$ day of storage respectively compared to other treatments followed by calcium nitrate $1 \% 5.70 \mathrm{~kg} / \mathrm{cm}^{2}$ recorded on $12^{\text {th }}$ day and also at all stages of storage intervals. The control fruits registered the lowest firmness $\left(3.80 \mathrm{~kg} / \mathrm{cm}^{2}\right)$ on $8^{\text {th }}$ day. In case of $2 \%$ calcium nitrate treated fruits the decline in firmness was gradual and maintained highest firmness up to 20 days storage $\left(2.70 \mathrm{~kg} / \mathrm{cm}^{2}\right)$, whereas in case of control fruits, the decline was found to be sharp. This reveals that $2 \%$ calcium nitrate treatment delays the softening process in mango fruits, and finally retained the desirable fruits firmness, which might be due to reduced transpiration loss and respiration activity and thus retained more turgidity of the cells. Decrease in fruit firmness during storage is presumably due to change in cell wall polysaccharides and this might be because of $\mathrm{Ca}$ being a constituent of pectate it might have made the middle lamella of fruit cell wall thicker by increased deposition of calcium pectate and thus, maintained the firmness of fruits (Singh and Narayana, 1999).

Ripening (\%): Maximum reduction in ripening was found in $2 \% \mathrm{Ca}\left(\mathrm{NO}_{3}\right)_{2}$ treated fruits followed by $1 \% \mathrm{Ca}$ 
T. Mounika et al. / J. Appl. \& Nat. Sci. 9 (4): 2055-2061 (2017)
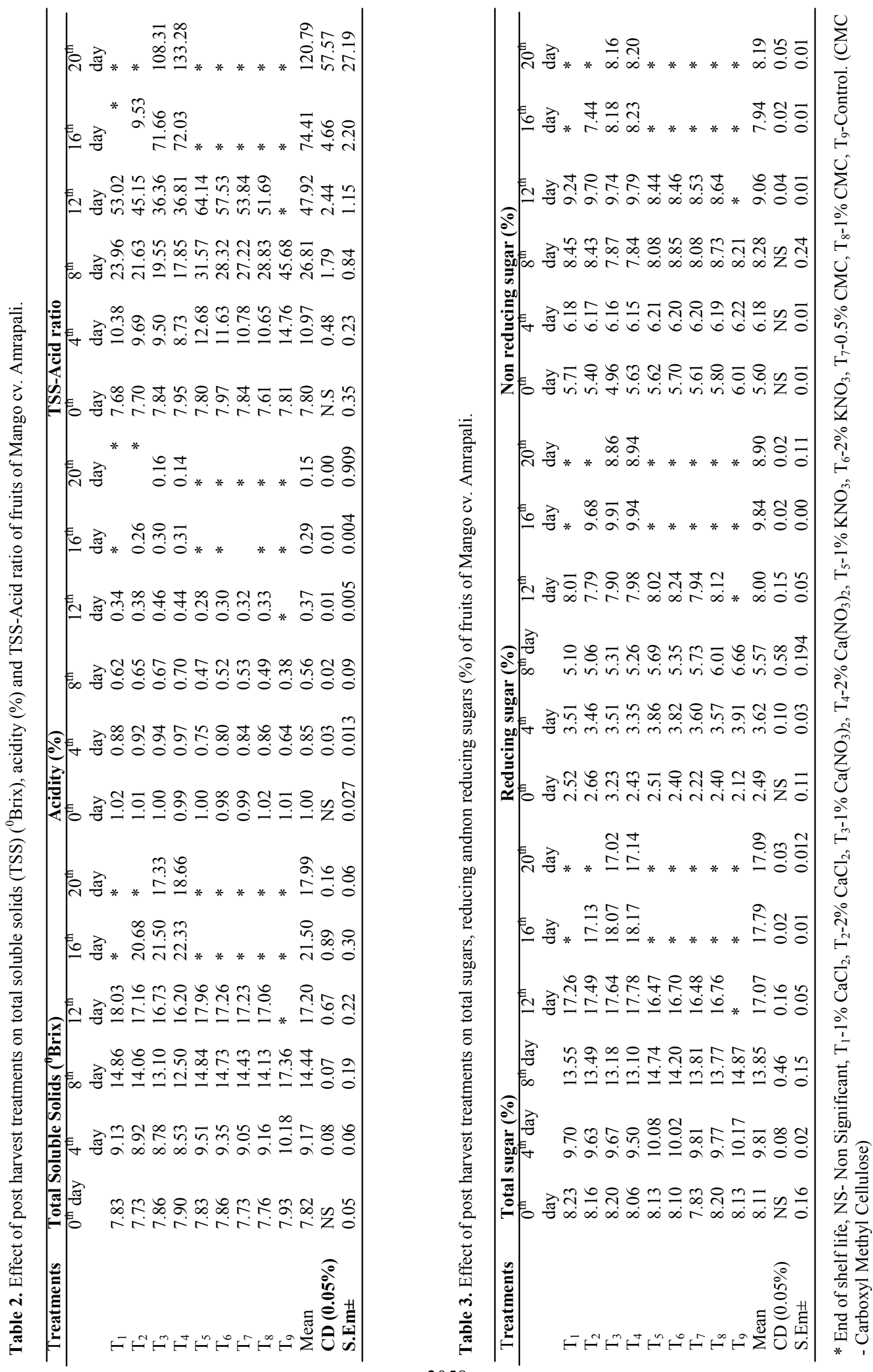
$\left(\mathrm{NO}_{3}\right)_{2}$ treated fruits while untreated control fruits reached the completed ripening within 12 days (Fig 1). On $20^{\text {th }}$ day of storage, $2 \% \mathrm{Ca}\left(\mathrm{NO}_{3}\right)_{2}$ treated fruits reached $73.33 \%$ of ripening whereas control fruits reached $48.66 \%$ of ripening on $8^{\text {th }}$ day. However, the percentage of ripe fruits increased significantly among the treatments.

Spoilage (\%): The minimum cumulative spoilage incidence $(19.83 \%)$ was recorded in fruits treated with $2 \%$ calcium nitrate, which was closely followed by fruits treated with $1 \%$ calcium nitrate with an incidence of $23.66 \%$ on $12^{\text {th }}$ day (Fig 1) compared to other treatments. Similarly lowest mean spoilage $(10.16 \%)$ was reported by Selvan and Bal (2005) in guava with application of calcium nitrate at 0.5 and $1 \%$. The maximum decay incidence was recorded in control (75.33)on $12^{\text {th }}$ day. The spoilage of fruits increased as the storage period advances. Among different chemical treatment, the spoilage was observed to be higher in fruits in control as compared to other treatments. Fruits soften due to ripening and senescent changes results in fruit softening which further predisposes it to the fungal pathogenic rots. The post harvest treatment of $2 \% \mathrm{Ca}\left(\mathrm{NO}_{3}\right)$ ${ }_{2}$ Was effective in significantly lowering the spoilage percent compared to other treatments. The spoilage of fruits increased with the increase in ripening and storage period. This may be due to association of calcium imparting a degree of resistance to decay by pathogens as per Conway (1985).

Shelf life (days): Shelf life of the mango fruits affected by post harvest treatments are presented in (Fig 1). The maximum shelf life (20.33days) of fruits was observed in $2 \%$ calcium nitrate followed by $1 \%$ calcium nitrate (18.0 days) whereas control recorded least shelf life of 9.66 days.Similar results were observed by Bharathi and Srihari(2004) in sapota with maximum shelf life of 12.33 days.

Total soluble solids (TSS): Total soluble solids (TSS) content increased slowly and steadily in all the treated fruits, after which decline in the TSS was recorded at the end of storage (Table 2). After $16^{\text {th }}$ days of storage interval the highest TSS $(22.33 \%)$ was recorded in mango fruits treated with $2 \%$ calcium nitrate, closely followed $21.50 \%$ TSS in fruits treated with $1 \%$ calcium nitrate.In fruits treated with $2 \%$ calcium nitrate, theTSS content increased slowly and steadily up to 16 days $(22.33 \%)$ and there after gradually declined after 16 days storage $(18.66 \%)$. The lowest average TSS $(11.82 \%)$ was observed in fruits kept as untreated (control). On the other hand, control fruits recorded increase in TSS up to $8^{\text {th }}$ day and then declined sharply afterwards.Post harvest treatment with $1 \%$ and $2 \% \mathrm{Ca}$ $\left(\mathrm{NO}_{3}\right)_{2}$ resulted in increase of TSS up to ripening and later decreased when prone to spoilage. The increase in TSS was mainly attributed to the conversion of starch and other polysaccharides into soluble forms of sugars (Mukherjee and Dutta (1967).Similarly,highest mean total soluble solid content $(11.50 \%)$ was observed by Selvan and Bal (2005) in guava with application of calcium nitrate at 0.5 and $1 \%$.

Acidity: The titratable acidity of mango fruits treated with different chemicals showed a linear declining trend with the advancement of storage periods (Table 2 ). The chemicals helped in better retention of acidity as compared to control. After $8^{\text {th }}$ day of storage interval the highest titratable acidity $(0.70 \%)$ was recorded in the fruits treated with $2 \%$ calcium nitrate, followed by $0.67 \%$ acidity in fruits treated with $1 \%$ calcium nitrate. The lowest titratable acidity $(0.38 \%)$ was recorded in control fruits. It is apparent from the data that titrable acidity showed constant decrease in treated and control fruits. The value of treated fruits was more than that of control fruits during the entire period of observation and there was gradual decrease in titrable acidity content of mango fruits with progress of storage periods. This could be attributed to the conversion of acids into sugars (Pool et al., 1972).

TSS-Acid ratio: There was a continuous increase in the mango fruit TSS-Acid ratio with the advancement of storage periods irrespective of different chemical treatment (Table 2). The fruitstreated with $2 \%$ calcium nitrate recorded highest TSS-Acid ratio (133.28) followed by treatments in which the fruits were treated with $1 \%$ calcium nitrate (108.31) whereas control fruits recorded 45.68 .The control fruits recorded the minimum average TSS-Acid ratio (23.14). Among the different treatments, mango fruits treated with $2 \%$ calcium nitrate retained highest average TSS-Acid ratio (46.12) of fruits rather than other treatments. TSS: acid ratio of mango fruit increased continuously throughout the storage period though TSS had slow initial increase followed by decrease. Reshi et al. (2013) on the performance of calcium role on litchi storage studies reported a continuous and significant decline in acidity $(0.41 \%$ to $0.22 \%)$, whereas, a gradual increase in TSS from 20.17 Brix to 26.64Brix (up to 6 days) and then decrease to 17.06 Brix (upto 10 days). Thus it can be inferred from the study that calcium increasesthe ratio of decrease in acidity is more compared to decrease in TSS in the later stage of storage.

Total sugar: The fruits treated with $2 \% \mathrm{Ca}\left(\mathrm{NO}_{3}\right)_{2}$ (Table 3) recorded maximum total sugar content $(18.17 \%)$. The control fruits recorded the lowest average total sugar content $(11.68 \%)$. It was further observed that fruits treated with $2 \% \mathrm{Ca}\left(\mathrm{NO}_{3}\right)_{2}$, the total sugar content increased slowly and steadily up to 16 days $(18.17 \%)$ and there after gradually declined after 16 days storage $(17.14 \%)$. In guava, maximum total sugars $(6.42 \%)$ was recorded in $1.0 \%$ calcium nitrate treatment whereas the minimum $(4.19 \%)$ in control on 12th day of storage (Raju, 2016). On the other hand, control fruits recorded a faster rise in total sugar content upto 8 days and there after declined at a faster rate at the end of storage. The delayed increase in TSS and 
total sugars over a longer period of time in $2 \% \mathrm{Ca}$ $\left(\mathrm{NO}_{3}\right)_{2}$ treated mango fruits might be attributed to delay in ethylene production and respiration rate of fruits. The increase in TSS/sugars during storage may possibly be due to break down of starch into sugars, as on complete hydrolysis of starch no further increase in sugars occurs and subsequently a decline in these parameters is predictable as they along with other organic acids are primary substrate for respiration (Wills et al., 1980).

Reducing sugars: Reducing sugars gradually increased in fruits with a slight decline at the end of storage periods, being significantly highest with $2 \% \mathrm{Ca}$ $\left(\mathrm{NO}_{3}\right)_{2}$ treated fruits $(9.94 \%)$ followed by $1 \% \mathrm{Ca}$ $\left(\mathrm{NO}_{3}\right)_{2}$ treated fruits $(9.91 \%)$ as compared to rest of the treatments (Table 3 ). The initial increase in reducing sugars might be due to the conversion of starch into reducing sugar and later on reduction could probably be due to utilization of sugar in the process of respiration. The percentage of reducing sugar increased slowly during storage period up to $12^{\text {th }}$ day and declined thereafter. The increase in reducing sugar might be due to increased rate of conversion of starch into reducing sugar by amylase activity. The increase in the total reducing sugar content is in line with the findings of Ingle et al., (1982) who reported an increase in reducing sugar content of sapota fruits during ripening. However, decrease in reducing sugar content (\%) was also observed due to over ripening of fruits which was utilized during respiration process.

Non reducing sugar: It was observed that the accumulation of non reducing sugar (\%) showed significant difference with respect to treatments and ripening stages of fruit, with a slight decline at over ripe stage being significantly highest with $2 \% \mathrm{Ca}\left(\mathrm{NO}_{3}\right)_{2}$ treated fruits $(8.23 \%)$ which was at par with $1 \% \mathrm{Ca}\left(\mathrm{NO}_{3}\right)_{2}$ treatment $(8.18 \%)$ as compared to the rest of the treatments (Table 3). The increase in the non-reducing sugar might be due to the hydrolysis of starch and conversion in the pectin substances from water insoluble to water soluble fractions. These results are in accordance with the findings of Hiwale and Singh (2003) in guava.

\section{Conclusion}

Fruits treated with $2 \% \mathrm{Ca}\left(\mathrm{NO}_{3}\right)_{2}\left(\mathrm{~T}_{4}\right)$, recorded significantly lower physiological loss in weight $(\%)$, higher fruit firmness, lower spoilage percent, good color development, lower ripening percentage and significantly higher acidity $(\%)$, TSS $\left({ }^{\circ} \mathrm{B}\right)$ and sugars $(\%)$ (reducing and total) correspondingly increased the shelf life up to 20.33 days compared to the fruits kept under control (9.33 days). Hence it can be concluded that calcium nitrate $(2 \%)$ treatment can be used for the post harvest storage of mango fruits.

\section{REFERENCES}

Anonymous.(1984). Official Methods of Analysis. Associa- tion of official Analytical Chemists (AOAC), 14th edition, Washington D.C. U.S.A.

Bharathi and Srihari.(2004) Post harvest treatment on storage life of sapota. M.Sc. Thesis submitted to Acharya N.G.Ranga Agricultural University, Hyderabad.

Bose, T. K., Mitra, S. K., Farooqui, A. A. and Sadhu, M. K. 1999.Tropical Hort. 1: 53-58.

Chung, H.D.,Kang, K.Y., Yun, S.J. and Kim, B.Y. (1993). Effect of foliar application of calcium chloride on shelflife and quality of strawberry. fruits. J. Korean. Soci. Hort. Sci., 34 (1) : 7-15.

Conway, W.S. and Sams, C.E.(1985). Influence of fruit maturity on the effect of postharvest calcium treatment on decay of 'Golden Delicious' apples. Plant Diseases. 69:42-44.

Hiwale, S. S. and Singh, S. P. 2003. Prolonging the shelf life of guava ( Psidium guajava L.). Indian J. Hort. 60: 1-9.

Ingle,G.S, Khedkar, D.M and Dabhade, R.S. (1981).Ripening studies in sapota fruits (Achras sapota L).Indian Food Packers.35:42-45.

Leopold, A.C. (1964).Plant growth and development, Mc Graw-Hill Book Company, New York 183-295.

Mahajan, B. V. C.; Randhawa, J. S. and Harminder Kaur Dhatt, A. S. (2008). Effect of post-harvest application of calcium nitrate and gibberellic acid on the storage life of plum. Ind. J. of Hort. 65(1): 94-96.

Mukherjee, S.K and Dutta, M.N. (1967).Physico chemical changes in Indian guava during fruitadevelopment.Currentscience.36:675-678.

Narendhra,B (2012). Poat harvest profile of mango,Directorate of marketing\& inspection, Nagapur.

National Horticulture Database.(2015-16).National Horticulture Board, Ministry of Agriculture, Government of India.http:nhb.gov.in/area-pro/database-2015.

Panse, V. G. and Sukhatme, P. V. (1967). Statistical Methods for Agricultural Workers, ICAR Publication, New Delhi, pp. 167-174.

Pulamte, Lalsiemlien. 2008. Key Issues in Post Harvest Management of Fruits and Vegetables in India. India Science and Technology: 2008: S\&T for Rural India and Inclusive Growth. http://www.nistads.res.in/ indiasnt2008/t6rural/t6rur14.htm.

Pool, R.M, Weaver, R.J and klliewer, W.M. (1972).The effect of growth regulator on changes in fruits Thomson seedless during cold storage.Journal of American society of horticultural sciences.97:67-70 .

Ranganna, S. (1979).Handbook of Analysis and Quality Control for Fruit and Vegetable Products. Tata McGraw -Hills Pub Co. Ltd., New Delhi,1111 p.

Ray, P.K. (1999).Mango hybrids developed in India. Tropical horticulture Vol. I. NayaPrakash, Calcutta, India. pp. 102-177.

Reshi, M. Kaul, R. K. Bhat, A. and Sharma, S. K. (2013). Response of post-harvest treatments on nutritional characteristics and shelf life of litchi cv. Dehradun. The Bionscan. 8(4): 1219-1222.

Rajudohre, 2016.Influence of post harvest treatments on shelf life and quality of guava (PsidiumguajavaL.) cv. Allahabad Safeda thesis submitted to RajmataVijayarajeScindiaKrishiVishwaVidyalaya. Gwalior.Madhya Pradesh.

Selvan, M. T. and Bal, J. S. (2005). Effect of different treatments on the shelf-life of Sardar guava during cold 
T. Mounika et al. / J. Appl. \& Nat. Sci. 9 (4): 2055-2061 (2017)

storage. J. R. P. Agri. University. 42(1): 28-33.

Singh, B.P and Narayana, C.K.(1995).Storagebehaviour of Dashehari mango in ventilated polybags.Indian Food Packer 49(1): 29-31.

Singh, $R K$ and Singh, $R N$. (2010). Effect of post harvest treatments on shelf life of Mango (Mangifera indica L.) fruits cv. Amrapali." Research Journal of Agricultural Sciences 1 (4): 415-18.

Wills, R.B.H, Cam bridge, P.A. and Scott, K.J. (1980). Use of flesh firmness and other objective tests to determine consumer acceptability of delicious apples. Australian J.Exp. Agri. Anim. Husb., 20: 252-56. 